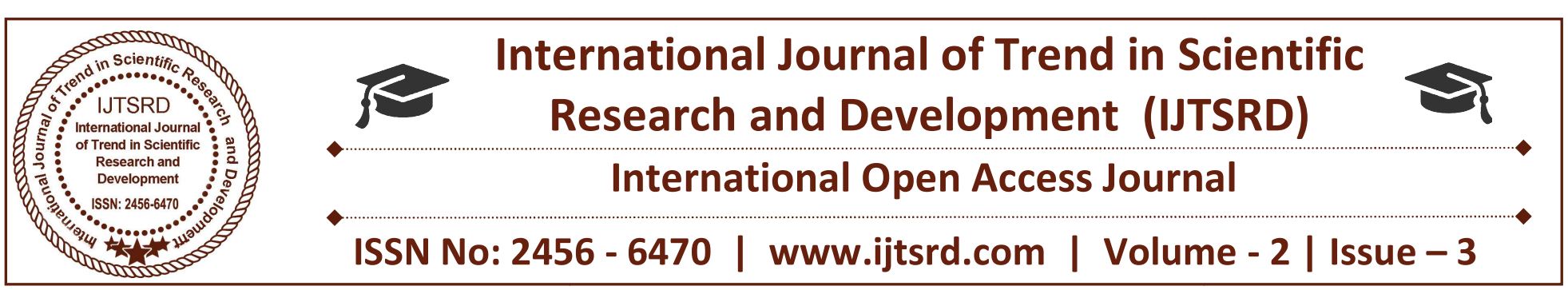

\title{
Experimental Study of Demolished Building Waste and Pet Bottles Used in Concrete
}

\author{
M. Iyappan ${ }^{1}$, Dr. K. C. Pazhani ${ }^{2}$ \\ ${ }^{1}$ Research Scholar, Department of Civil Engineering, \\ ${ }^{2}$ Associate Professor, Division of Structural Engineering \\ ${ }^{1,2}$ Anna University, Guindy, Tamil Nadu, India
}

\begin{abstract}
A modern lifestyle, alongside the advancement of technology has led to an increase in the amount and type of waste being generated, leading to a waste disposal crisis. This study tackles the problem of the waste that is generated from construction fields, such as demolished building wastes and waste pet bottles. In order to dispose of or at least reduce the accumulation of certain kinds of waste, it has been suggested to reuse some of these waste materials to substitute a percentage of the primary materials used in the ordinary portland cement concrete (OPC).The waste materials considered to be recycled in this study consist of plastics, and demolished building waste. Such recycling not only helps conserve natural resources, but also helps solve a growing waste disposal crisis. Pet bottles were used to replace up to $3 \%$ of cement in concrete mixes, while crushed concrete was used to replace up to $25 \%, 50 \%, 100 \%$ of coarse aggregates. To evaluate these replacements on the properties of the OPC mixes, a number of laboratory tests were carried out. These tests included compressive strength, flexural strength, and indirect tensile strength (splitting). The main findings of this investigation revealed that the two types of waste materials could be reused successfully as partial substitutes for cement or coarse aggregates in concrete mixtures.
\end{abstract}

\section{INTRODUCTION GENERAL}

Concrete is an indisputable material for the construction of various types of structures in the modern advancement of civil infrastructures. Concrete and cement based materials have been implemented in structural members since prehistoric times. Day by day the implication of concrete has been developed

and the limitations of concrete have been slowly but surely eliminated which increases the durability of concrete allowing a higher performance value to be achieved. However, concrete is strong in compression but weak in tension.

Plain concrete possess a very low tensile strength, limited ductility and little resistance to cracking. Internal micro cracks are inherently present in the concrete and its poor tensile strength is due to the propagation of such micro cracks eventually leading to the brittle fracture of the concrete.

To overcome this weakness in concrete, steel reinforcement is used to carry the tensile forces and prevent any cracking or by pre-stressing the concrete so it remains largely in compression under load.

In the past, attempts have been made to impart in tensile properties of concrete members in the past by way of using conventional reinforced steel bars and also by applying restraining techniques. Although both these methods provide tensile strength to the concrete members, they do not increase the inherent tensile strength of the concrete itself.

In the plain concrete and similar brittle materials, (micro) cracks develop even before loading, particularly due to drying shrinkage or other causes of volume change. The width of these initial cracks seldom increases a few microns, but their other two dimensions may be of higher magnitude.

When loaded, the micro cracks propagate and open up, and owing to the effect stress concentration, additional cracks form in places of minor defects. The 
structural cracks proceed slowly or by tiny jumps because they are retarded by various obstacles, changes of direction in bypassing the more resistant grains in the matrix. The development of such micro cracks is the main cause of inelastic deformations in concrete.

Therefore, the introduction of fibers was brought in as an alternative to developing concrete in view of enhancing its flexural and tensile strengths (Banthia $\mathrm{N}$ and Sheng J, 1996). Although the basic governing principles between conventional reinforcement and fiber systems are identical, there are several characteristic variations; such as - fibers are generally short, closely spaced and dispersed throughout a given cross section but reinforcing bars or wires are placed only where required (Kosmatka S et al., 2002). For this reason fibers have been used to improve the toughness and ductility of concrete. It is used in industrial floors, tunneling, mining, security structures, heavy duty pavements, slab types members, runways of airport where conventional reinforcement are impractical (Clarke J et al., 2007).

The word "plastic" means substances which have plasticity, and accordingly, anything that is formed in a soft state and used in a solid state can be called a plastic. Therefore, the origin of plastic forming can be traced back to the processing methods of natural high polymers such as lacquer, shellac, amber, horns, tusks, tortoiseshell, as well as inorganic substances such as clay, glass, and metals. Because the natural high polymer materials are not uniform in quality and lack mass productivity in many cases, from early times it has been demanded in particular to process them easily and into better quality and to substitute artificial materials for natural high polymers. Celluloid, synthetic rubber, ebonite, and rayon are these artificial materials. Presently, it is defined that the plastics are synthesized high polymers which have plasticity, and consequently substances made of these natural materials are precluded. Plastics can be separated in to two types.

The first type is thermoplastic, which can be melted for recycling in the plastic industry. These plastics are polyethylene, polypropylene, polyamide, polyoxymethylene, polytetrafluorethylene, and polyethyleneterephthalate. The second type is thermosetting plastic. This plastic cannot be melted by heating because the molecular chains are bonded firmly with meshed crosslink. These plastic types are known as phenolic, melamine, unsaturated polyester, epoxy resin, silicone, and polyurethane. At present, these plastic wastes are disposed by either burning or burying. However, these processes are costly. If the thermosetting plastic waste can be reused, the pollution that is caused by the burning process as well as the cost of these waste management processes can be reduced. To achieve this purpose, a study of these thermosetting plastics for application into construction materials has been conducted, particularly for the concrete wall in buildings. In Thailand, lightweight concrete is extensively used for the construction of interior and exterior walls of buildings for the case where the walls are not designed for lateral loads. This is due to the special characteristics of lightweight concrete.

Research concerning the use of by-products to augment the properties of concrete has been going on for many years. In the recent decades, the efforts have been made to use industry by-products such as fly ash, silica fume, ground granulated blast furnace slag (GGBS), glass cullet, etc., in civil constructions. The potential applications of industry by-products in concrete are as partial aggregate replacement or as partial cementer placement, depending on their chemical composition and grain size. The use of these materials in concrete comes from the environmental constraints in the safe disposal of these products. Big attention is being focused on the environment and safeguarding of natural resources and recycling of wastes materials. Actually many industries are producing a significant number of products which incorporate scrap (residues). In the last 20 years, a lot of works concerning the use of several kinds of urban wastes in building materials industrials process have been published. Many researches have been extended to study new kinds of wastes to investigate deeply particular aspects. The addition of wastes, apart from the environmental benefits, also produces good effects on the properties of final products. One of the new waste materials used in the concrete industry is recycled plastic. For solving the disposal of large amount of recycled plastic material, reuse of plastic in concrete industry is considered as the most feasible application. Recycled plastic can be used as coarse aggregate in concrete. However, it is important to underline that re-using of wastes is not yet economically advantageous, due to the high costs of transport and its effect on the total costs of production. Moreover, it is important not to neglect other costs, directly referable to the kind of wastes, 
due, in particular, to the need of measuring gas emission, during firing, and the presence of toxic and polluting elements.

Approx. 90 per cent of the total concrete waste is generated during construction, demolition and renovation of buildings, of which demolition is responsible for three quarters. There are no statistics on concrete waste from other types of constructions (bridges, quays, pipelines, curb stones, etc.). Against the background of communications from the Norwegian Public Roads Administration, the Port Authority, the Norwegian National Rail Administration and others, we have estimated that construction in these sectors produces approx. 30000 tonnes of concrete waste, or about 3 per cent of the total concrete waste.

Concrete waste is also generated during the production of concrete products and ready-mix concrete. On the basis of production data, it has been estimated that this industry generates around 80000 tonnes of production waste, which constitutes 7 per cent of the total quantity of concrete and brick waste in 1999.

\section{FIBER REINFORCEMENT}

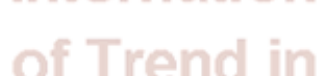

The primary of function of fiber or reinforcement is to carry load along the length of fiber to provide strength and stiffness in the one direction .reinforcement can be oriented to provide tailored properties in the direction of the load imported on the end of the product the reinforcement can be both natural and manmade. The fibers are mainly classified in two types namely
$>$ Natural fibers
$>$ Synthetics fibers or manmade fibers
$>$ Animal Fiber
$>$ Plant Fiber
$>$ Mineral Fiber

\section{Natural Fibers}

Fibers under this category are composed of naturally occurring minerals. coconut coir bamboo, sisal, pineapple, cotton, jute, and banana fibers are examples for natural occurring natural fibers.

Synthetic Fibres

Synthetic fibers are the result of extensive research by scientists to improve upon naturally occurring animal and plant fibers. In general, synthetic fibers are created by forcing, usually through extrusion, fiber forming materials through holes into the air, forming a thread.

\section{Animal Fibers}

Animal fiber generally comprise proteins; examples mohair, wool, silk, alpaca, angora. Animal hair (wool or hair) are the fibers taken from animals or hairy mammals. E.g. Sheep's wool, goat hair (cashmere, mohair), alpaca hair, horse hair, etc. Silk fibers are the fibers collected from dried saliva of bugs or insects during the preparation of cocoons.

Examples include silk from silk worms. Avian fiber is the fibers from birds, e.g. feathers and feather.

\section{Mineral Fiber}

Mineral fibers are naturally occurring fiber or slightly modified fiber procured from minerals. These can be categorized into the following categories: Asbestos is the only naturally occurring mineral fiber. Variations are serpentine and amphiboles, anthophyllite. Ceramic fibers includes glass fibers (Glass wood and Quartz),aluminum oxide, silicon carbide, and boron carbide. Metal fibers include aluminum fibers.

\section{Plant Fiber}

\section{Plant Fiber}

Plant fibers are generally comprised mainly of cellulose: examples include cotton, jute, flax, ramie, sisal and hemp. Cellulose fibers serve in the manufacture of paper and cloth. This fiber can be further categorizes into following as: Seed fiber are the fibers collected from the seed and seed casing. Cotton and kapok. Leaf fibers are the fibers collected from the leaves e.g. sisal and agave. Skin fibers are the fibers are collected from the skin or baste surrounding the stem of their respective plant. These fibers have higher tensile strength than other fibers. Therefore, these fibers are used for durable yarn, fabric, packaging, and paper. Some examples are flax, jute, banana, hemp, and soybean. Fruit fiber is the fibers are collected from the fruit of the plant, e.g. coconut (coir) fiber. Stalk fiber are the fibers are actually the stalks of the plant.

\section{Benefits of Fiber Reinforced Concrete}

1. Controlled Plastic Shrinkage

2. Minimized Crack Growth

3. Reduced Permeability

4. Improved Surface Durability

5. Uniform Reinforcement In all Directions 
WHY POLYETHYLENE TEREPHTHALATE (PET) AS A FIBRE?

Polyethylene Terephthalate (PET) is used as a fibre reinforcing material in concrete for the following reasons

1. It has a high tensile strength which is equal to that of a copper wire with similar diameter.

2. Polyethylene Terephthalate (PET), a nondegradable matter is creating an environmental problem so its use as a fibre reinforcing material can minimize the problem.

3. It is also available in abundance and at a very low cost.

4. It reinforces the mortar and prevents it from spalling.

Polyethylene Terephthalate (PET) is one of the most important synthetic fibers for industrial production. The largest use of PET currently is in containers. In this area, beverage and mineral water bottles are standing in prime position. The current worldwide production of PET exceeds 6.7 million tons/year and shows a dramatic increase in the Asian region due to recent increasing demands in China and India (Kim et al., 2009). Last decade, few studies were done on mechanical behaviour of PET-FRC and fiber itself. Semiha A et al. (2009) investigated PET bottle granules as a light weight aggregate in mortar and reported some advantages; such as - reduction in the death weight of a structural concrete member of a building which help to reduce the seismic risk of the building, reduction in the use of natural resources, disposal of wastes, prevention of environmental pollution and energy saving.

\section{NEED FOR STUDY:}

Construction and demolition waste (C\&D) constitutes a major portion of total solid waste production in the world, and for the present most of it is used in landfills. The most effective way to reduce the waste problem in construction is agreed in implementing reuse, recycling and reduced the use of a construction material in construction activities. Those " $3 \mathrm{R}$ " are the positive influence on Economy, Ecology and Energy.

Application of recycled materials in the building industry is important for sustainable development and keeping of primary sources of each country. Recycling and reuse of building rubble presents interesting possibilities for economizing on waste disposal sites and conserving natural resources.
There is whole range of applications of recycled materials for civil engineering structures and it is necessary seek the other possibility in re-use of those building materials whose live-span has been finished.

C \& DW as crushed concrete or masonry (brick) are mineral inorganic materials with inert behaviour, without dangerous properties and without significant physical, chemical or biological change. Because of the difference in properties of recycled material and possible uncertainties in origin of the recycled rubble it might be difficult to provide and guarantee considered properties in concrete. This is probably reason that recycled aggregate is used mainly for nonstructural applications at present such as a road base or a backfill. The idea to add fibres to a concrete mixture with recycled aggregate may change material properties of such concrete, improve behaviour, bring about new types of applications and enables saving sources of natural aggregate. This work as thesis aims to reduce the demand for primary aggregates by using crushed C \& DW as an alternative.

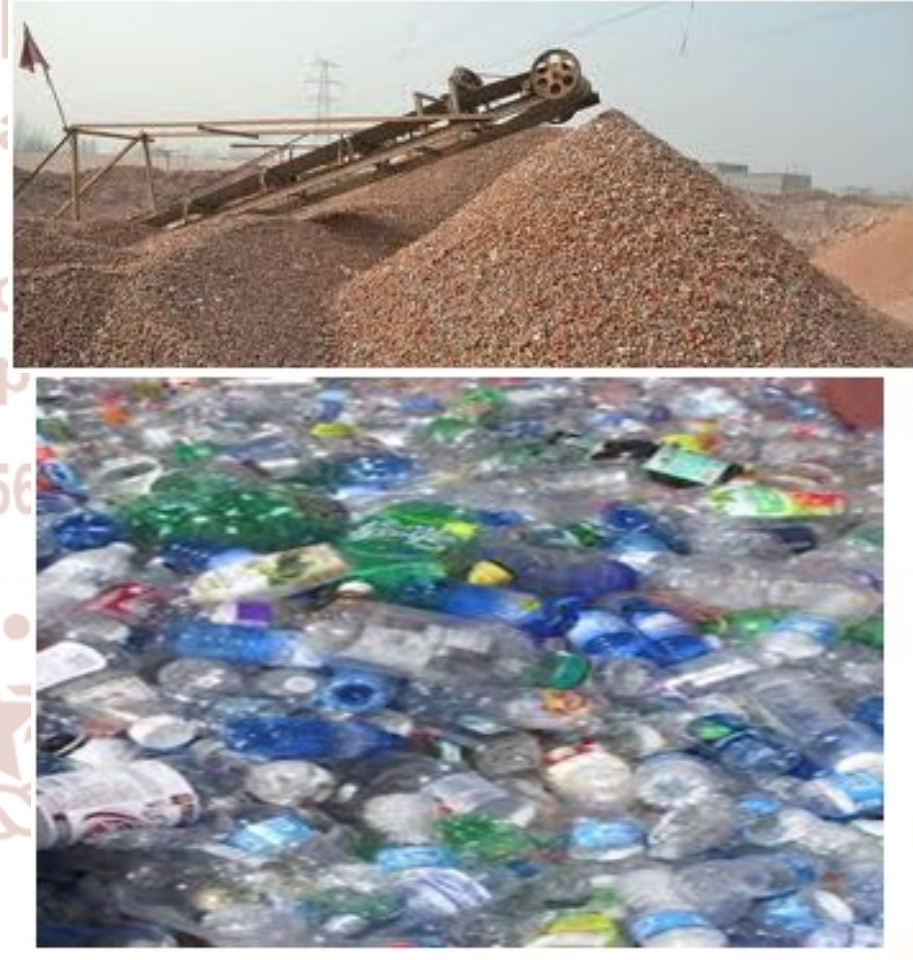

\section{SCOPE}

The present Indian concrete industry is consuming about 370 million $\mathrm{m} 3$ of concrete every year and it is expected, that it shall reach about 580 million $\mathrm{m} 3$ by 2022. The re-formation of natural sources is beyond the proportion of mankind. Hence the increased demand of concrete has raised a serious question on the quickly vanishing valuable natural sources. It is therefore has become a necessity to find an alternate material could be used along with the conventional 
materials and try to reduce the quick and huge usage of valuable sources. A new term evolved called Green concrete - it is a concrete prepared by using the waste products of different industries with the conventional materials. Wide variety of such wastes are already being added and tested for various observations and their effects on different aspects of concrete properties.

\section{OBJECTIVES}

$>$ To study the use of recycled aggregate and pet bottle in concrete, in which aggregate are replaced by recycled aggregate $(0 \%, 25 \%, 75 \%, 100)$ and cement are partially replaced by pet bottle $(0 \%, 1 \%, 2 \%, 3 \%)$ into the concrete, then the following test are to be conducted.

- Compressive Strength of concrete

- Flexural Strength of concrete

- Split tensile test of concrete

Compare the test results with Conventional concrete.

\section{METHODOLOGY}

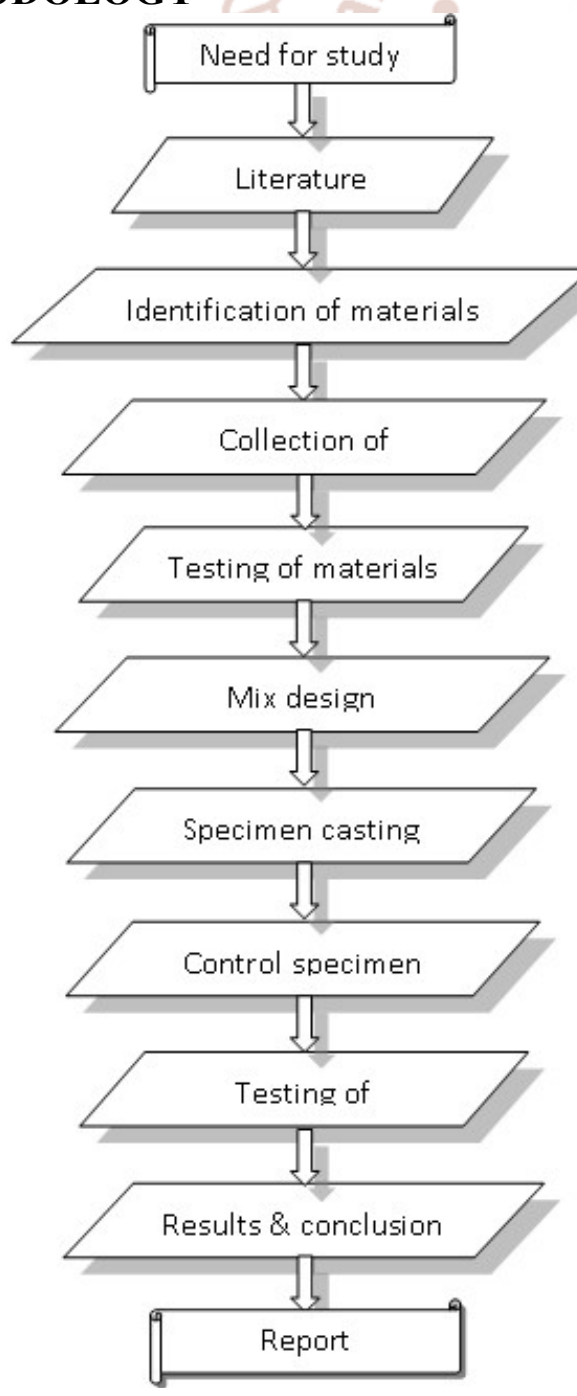

M

\section{LITERATURE VIEW}

Professor Y P Gupta describes in the journal "Use of Recycled Aggregate in Concrete Construction: A need for Sustainable environment" (August 2009) the outcome of tests carried out about the use of Recycled Aggregate in Construction. A process to get aggregate from demolition waste is developed and its basic properties are determined. These properties are compared with conventional and local aggregate. Such recycled aggregate is tried to produce concrete of grades equivalent to M25 or similar other uses. It is found that Recycled Aggregate from demolition Waste can be gainfully used in making fresh Concrete for general construction purposes, Concrete Blocks / Bricks and for rigid pavements in under layers like DLC etc. The most useful item is making Conventional Bricks similar to burnt clay bricks. 
footings for posts and fences, and mass concrete fill which does not sustain appreciable loading.

> Bayasi and Zeng (1993) investigated the influence of polypropylene fibers on the impact resistance of concrete. They concluded that polypropylene fiber enhanced the impact resistance of concrete significantly. This was especially true for 12.7 $\mathrm{mm}$ long fibers. These fibers significantly increased the impact resistance of concrete for volumes that do not affect mix workability (less than $0.5 \%$ ), while, at higher volume contents, impact resistance may tend to decrease

$>$ Choi et al. (2005) studied the effects of polyethylene terephthalate (PET) bottles lightweight aggregate (WPLA) on the compressive strength of concrete. Mixture proportions of concrete were planned so that the water-cement ratios were $45 \%, 49 \%$, and $53 \%$, and the replacement ratios of WPLA were $0 \%$, $25 \%, 50 \%$, and $75 \%$ by volume of fine aggregate. It is found that compressive strength of concrete mixtures decreased with the increase in PET aggregates and for a particular PET aggregate content, compressive strength increased with the reduction in $\mathrm{w} / \mathrm{cm}$ ratio.

$>$ Soroushian et al. (2003) studied the effect recycled plastic on the impact resistance of concrete. The impact test involved repeated dropping of a standard hammer from a particular height until a $63.5 \mathrm{~mm}$ concrete cylinder with a $152.4 \mathrm{~mm}$ diameter exhibited failure (Balaguru and Shah., 1992).Different fibers provided different geometric, bond, and stiffness characteristics, which explains rather significant differences observed in the improvements in impact resistance brought about by different fiber reinforcement systems.

$>$ Soroushian et al. (2003) investigated the effect of recycled plastic on the abrasion resistance of concrete. Most discrete reinforcement systems were observed to cause some reduction of the abrasion resistance of concrete (reflected in increased mass loss in the presence of fibers). This effect could result from the fact that fibers occurring near the surface could debond under abrasion effects, thereby contributing to mass loss; change in the bleeding characteristics of concrete in the presence of fibers could also modify surface characteristics of concrete and thus its abrasion resistance

$>$ Choi et al. (2005) investigated the effect of polyethylene terephthalate (PET) bottles lightweight aggregate (WPLA) on the modulus of elasticity of concrete. Mixture proportions of concrete were planned so that the water-cement ratios were $45 \%, 49 \%$, and $53 \%$, and the replacement ratios of WPLA were $0 \%, 25 \%, 50 \%$, and $75 \%$ by volume of fine aggregate.

The modulus of elasticity of concrete mixtures decreases with the increase in percentage of aggregates

Marzouk et al. (2007) also observed that modulus values decrease as PET quantity increases. For example, at a 50\% substitution rate, a 50\% reduction of modulus of elasticity was noted, in comparison with the reference mortar .Reduction in modulus of elasticity is due both to the reduction of composite bulk densities and to plastic aggregates, which decrease the celerity of wave by disturbing the ultrasonic wave propagation. This finding indicates the positive influence from substituting siliceous aggregates with plastic aggregates on the durability of mortar and its behaviour with vibrations.

Al-Manaseer and Dalal (1997) reported the effects of plastic aggregates on the modulus of elasticity of concrete. They concluded that the value of modulus of elasticity decreased with the increase in plastic aggregate content. Depending upon w/c ratio, modulus of elasticity was found to vary between $24.3 \mathrm{GPa}$ for concrete containing no aggregates $(\mathrm{w} / \mathrm{c}=0.28)$ to $8.6 \mathrm{GPa}$ for concrete containing $50 \%$ plastic aggregates $(\mathrm{w} / \mathrm{c}=0.50)$. In general, increase in $\mathrm{w} / \mathrm{c}$ ratio decreased the modulus of elasticity of concrete.

Choi et al. 2005) found that the flexural strength of new composites decreases regularly with the increase in percentage of plastics in concrete. For $50 \%$ replacement of aggregates by plastics, the flexure strength reaches $32.8 \%$ of the reference concrete.

$>$ Marzouk at al.(2007) studied that the flexural strength of new composites decreases regularly as the volume of PET(expanded plastic) recycled aggregate increases.

$>$ Babu et al (2004)reported that the splitting tensile strength decreases with increase in the EPS(expanded plastic) volume percentage and with higher EPS(expanded plastic) concretes showed the gradual splitting whereas in the lower volume of EPS(expanded plastic) concretes the splitting was somewhat sudden, though not like normal concretes. 
$>$ Jo et al. (2007) studied the effect of recycled aggregates and resins on tensile strength of concrete. In the case of split tensile strength they observed that there was a slight increase in the strength of RPC made with a resin content of $13 \%$ compared to RPC made with a resin content of $9 \%$. This increase was predicted to be due to the different and complex failure mechanisms of the material in RPC under tension

> Bataynehet al. (2007)observed similar behavior, in splitting and flexural strengths of the tested samples. The reduction in strength is due to the fact that the strength of the plastic particles is lower than that of the aggregate. Therefore, both the use of concrete with plastic particles and the percentage of replacement should be controlled, according to the allowable strength of the structural element to be constructed

Choi et al. (2005) studied the influence of polyethylene terephthalate (PET) bottles lightweight aggregate (WPLA) on the splitting tensile strength of concrete. Mixture proportions of concrete were planned so that the water-cement ratios were $45 \%, 49 \%$, and $53 \%$, and the replacement ratios of WPLA were $0 \%, 25 \%, 50 \%$, and $75 \%$ by volume of fine aggregate. Splitting tensile strength of concrete mixtures was observed to decrease with the increase in PET aggregates; and for a particular PET aggregate content, splitting tensile strength increased with the reduction in $\mathrm{w} / \mathrm{cm}$ ratio

$>$ Naik et al. (1996) investigated the effect of postconsumer waste plastic in concrete as a soft filler. Thew test results showed lower compressive strength of the mix made with plastics than the reference mixture without plastic. This was attributed to lower compressive strength of the plastic particles compared to cementitious matrix as well as natural fine and coarse aggregates. The effect of various treatment son plastics was also studied and it was concluded that out of the three treatments used on the plastics, alkaline bleach treatment is best with respect to compressive strength of concrete.

$>$ Ghaly et al. (2004) conductedresearch on plastic chips that were used as partial replacement of coarse aggregates in concrete mixtures. In this study, plastic aggregates 42 replaced 5, 10 and $15 \%$ by mass of coarse aggregates. It was found that for a given $\mathrm{w} / \mathrm{c}$ ratio, the greater the plastic content in the mix, the lower is the compressive strength of concrete. Digital imaging of concrete cube sections with plastics showed that the plastics were well dispersed in the concrete.

$>$ Jo et al.(2007)studied the effect of recycled aggregates and resins on compressive strength of concrete. In recycled-PET polymer concrete with recycled concrete aggregates (RPC), a gradual reduction in strength was observed as the recycled aggregate content increased. This effect was due to the weaker bond of the old mortar adhering to the recycled concrete aggregate, which may have caused a reduction in the strength of the RPC. Studying the influence of resin on properties of concrete, it was observed that the compressive strength of RPC increased with resin content. However, beyond certain resin content (approximately 13-17\% resin) the strength did not change appreciably with increasing resin content. The increase in strength with the use of resin was due to the voids in the old mortar attached to the recycled aggregate

Babuet al. (2004)concluded that compressive strength showed an increasing trend as the age increases and also the percentage of increase in almost all the mixes at 7 days to 28 days and 28 days to 90 days was even higher than $35 \%$. The strength decreases with the increase of EPS(expanded plastics)percentage (i.e., varying linearly with the density of the concrete).

Marzouk at al(2007)has presented that the variations in the compressive strength of composites as a function of the volumetric percentage of recycled aggregate substitutes used. It can initially be seen, that once the sand volume substituted with aggregates increased from $0 \%$ to $50 \%$, the compressive strength of composites decreased slightly, by $15.7 \%$ in comparison with the reference mortar. However, these various values are higher than the 28-day compressive strengths obtained in previous works

$>$ Batayneh et al. (2007) demonstrated in their study that the addition of the plastic particles led to a reduction in the strength properties. For a $20 \%$ replacement, the compressive strength shows a sharp reduction up to $72 \%$ of the original strength. With 5\% replacement the compressive strength shows a $23 \%$ reduction.

Bayasi and Zeng (1993) reported the effects of polypropylene fibers on the compressive strength of concrete. The compressive behaviour characteristics of concrete are studied in terms of compressive strength and toughness index. Compressive toughness index is defined as the 
total compressive energy absorbed (total area under compressive stress-strain curve) divided by the pre-peak compressive energy absorbed (area under the stress-strain diagram up to peak stress).

(Siddique, 2007).It was concluded that $19 \mathrm{~mm}$ fibrillated polypropylene fibers had no obvious effect on the compressive strength of concrete. However, $19 \mathrm{~mm}$ fibrillated polypropylene fibers enhanced the energy absorption and toughness characteristics of concrete under compression, as evidenced by increase in compressive toughness index of concrete with fiber addition

Marzouk (2007) studied the innovative use of consumed plastic bottle waste as sand-substitution aggregate within composite materials for building application. Bottles made of polyethylene terephthalate (PET) were used as partial and complete substitutes for sand in concrete composites. Various volume fractions of sand varying from $2 \%$ to $100 \%$ were substituted by the same volume of granulated plastic, and various sizes of PET aggregates. They concluded that substituting sand at a level below $50 \%$ by volume with granulated PET, whose upper granular limit equals $5 \mathrm{~mm}$, affected the compressive strength of composites and plastic bottles shredded into small PET particles may be used successfully as sandsubstitution aggregates in cementitious concrete composites. These composites appeared to offer an attractive low-cost material with consistent properties; moreover, they would help in resolving some of the solid waste problems created by plastics production and in saving energy.

Batayneh et al. (2007) investigated the effect of ground plastic on the compressive strength of concrete. Concrete mixes of up to $20 \%$ of plastic particles are proportioned to partially replace the fine aggregates. They concluded that the addition of plastic particles led to a reduction in the strength properties. For a $20 \%$ replacement, the compressive strength exhibited a sharp reduction of up to $72 \%$ of the original strength. With $5 \%$ replacement, the compressive strength showed a $23 \%$ reduction. This reduction in strength was due to the fact that the strength of the plastic particles is lower than that of the aggregate. They concluded that both the use of concrete with plastic particles and the percentage of replacement should be controlled, according to the allowable strength of the structural element to be constructed.
Professors C. S. Poon, S. C. Kou and L. Lam have aimed to develop a technique for producing concrete bricks and paving blocks using recycled aggregates obtained from construction and demolition waste. Laboratory trials were conducted to investigate the possibility of using recycled aggregates from different sources in Hong Kong, as the replacement of both coarse and fine natural aggregates in molded bricks and blocks. A series of tests were carried out to determine the properties of the bricks and blocks prepared with and without recycled aggregates. The test results showed that the replacement of coarse and fine natural aggregates by recycled aggregates at the levels of 25 and $50 \%$ had little effect on the compressive strength of the brick and block specimens, but higher levels of replacement reduced the compressive strength. However, the transverse strength of the specimens increased as the percentage of replacement increased. Using recycled aggregates as the replacement of natural aggregates at the level of up to $100 \%$, concrete paving blocks with a 28-day compressive strength of not less than $49 \mathrm{MPa}$ can be produced without the incorporation of fly ash, while paving blocks for footway uses with a lower compressive strength of $30 \mathrm{MPa}$ and masonry bricks can be produced with the incorporation of fly ashes.

Professor Marius-Teodor Muscalu and Radu Andrei in their Paper Presentation "Use of Recycled Aggregates in Rigid Pavement Construction" (March 2011) explained how to produce recycled aggregates with physicalmechanical characteristics suitable for use in rigid pavement construction. Recycled aggregates under investigation are obtained by crushing of cement concrete from the demolition of buildings in IAŞI municipality. The main objective of the research is to achieve a higher economic value of the cement concrete resulted from demolitions by recycling and use in the construction of conventional cement concrete pavements (PCCplain cement concrete) and roller compacted concrete pavements (RCC). An important benefit resulting by using recycled aggregates in pavement engineering is the reduction of the impact of construction works on the environment by both limiting the exploitation of natural aggregates and the use of landfill construction and demolition wastes. Finally, a technical evaluation of the investigated recycled aggregates quality, in 
accordance with existing standards and norms, will be considered.

> Al-Manaseer and Dalal (1997) investigated the effect of plastic aggregates on the bulk density of concrete. They concluded that the bulk density of concrete decreased with the increase in plastic aggregates content. The reduction in bulk density was found to bedirectly proportional to the plastic aggregates content, density of concrete reduced by $2.5 \%, 6 \%$, and $13 \%$ for concrete containing $10 \%$, $30 \%$, and $50 \%$ plastic aggregates, respectively. Reduction in density was attributed to the lower unit weight of the plastics

$>$ Prof. Young P. C and Teo D C L have described in the journal, "Utilisation of Recycled Aggregate as Coarse aggregate in concrete" that the recycled concrete aggregates (RCA) from site-tested concrete specimens were used. These consist of 28 days concrete cubes after compression tests from local construction site. These concrete cubes are crushed to suitable size and reused as recycled course aggregate. The amount of recycled concrete aggregate used in this research is approximately $200 \mathrm{~kg}$. Many researches state that recycled aggregates are only suitable for nonstructural concrete application. This research however shows that the recycled aggregates are obtained from the site-tested concrete specimen make good quality concrete. The compressive strength of recycled aggregate concrete is found to be higher than the compressive strength of normal concrete. Recycled aggregate concrete (RAC) is in close proximity to normal concrete in terms of split tensile strength, flexural strength and wet density. The slump of recycled aggregate concrete is low and that can be improved by using saturated surface dry (SSD) coarse aggregate.

$>$ Professor V. Vytlačilová has stated in the journal, "The fibre reinforced concrete with using recycled aggregate" that based on a large series of acquired experimental results on different characteristics of the tested material, it can be judged on the behaviour of this composite. The previous experimental program has proved that the properties of this concrete are sufficient enough to be used in ground structures as intended. Fibre concrete with recycled aggregate is looking for potential usage in present. One of possible applications of fibre-concrete composite is strengthening of layers in earth structures as levees, dams or dikes. Inserting of slabs in the body of the earth structures contribute to stability and higher resistance of the structures. The slope or dam may have steeper sloping, what reduce earthmoving work. Inserting of fibre-concrete slabs into dam enhanced resistance of the dam in case of spill-over that may happen during floods. In the case of preparation of fibre concrete for the intended reinforcing slabs for experimental model (Fig. 3.2), which are inserted in the earth structures, the recycled material can be limited by the maximum particle size according to the thickness of the design slab and the length of the synthetic fibres, whose use in the fibre concrete is anticipated. The recycled aggregate graded according to this limitation can be characterized as to be of the so-call wide grading curve. The fibre concrete with the recycled aggregate with this characteristic is beneficial in the presented applications both in the fresh and hardened state.

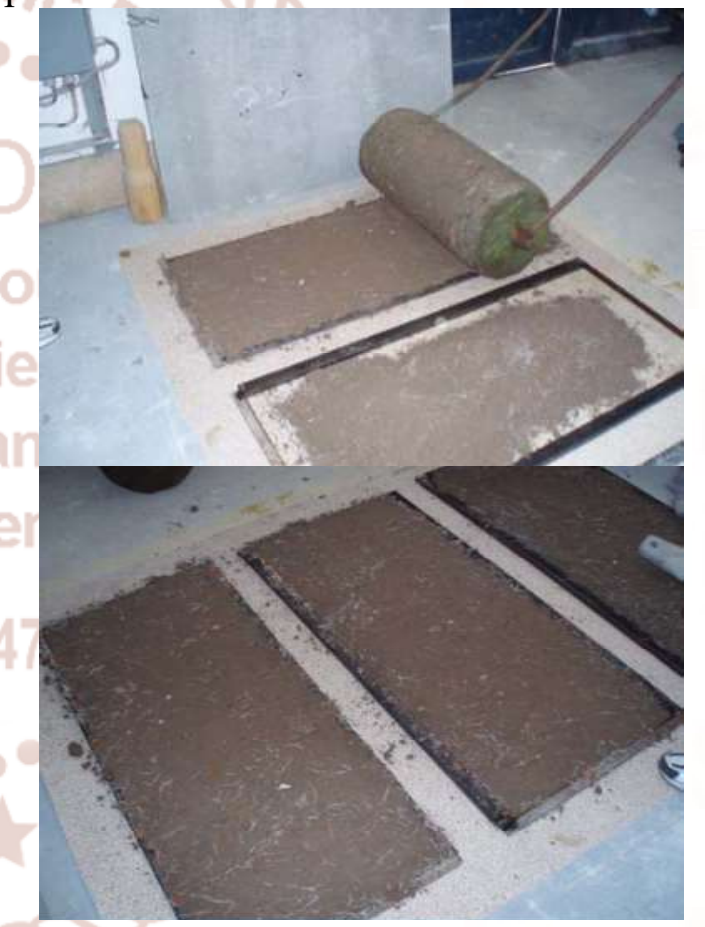

Fig. 3.2 - The Preparation of Slabs from Fibre Concrete

For a supposed application we can state

Fibre concrete is porous and thus it is not waterresisting,

$>$ The pores and gaps contribute to the interaction with the surrounding earth, with increases the effect of the inserted slabs in the case of earth structures,

$>$ The porous structure of the composite allows higher ductility in tension under the condition, when the dispersed synthetic fibres are anchored with the hydrated cement paste to the recycled aggregate. 


\section{Cement}

It can be defined as material having adhesive and cohesive properties which make it capable of binding material fragments in to a compact mass. Cement is obtained by burning together in a definite proportion, a mixture of naturally occurring calcareous (containing calcium carbonate or lime) and argillaceous (containing alumina) material to be partial fusion at high temperature about $1450^{\circ} \mathrm{C}$. The four major compounds are:

$>$ Tricalcium silicate $\left(3 \mathrm{CaO} \cdot \mathrm{SiO}_{2}\right)$

$>$ Dicalcium silicate $\left(2 \mathrm{CaO} \cdot \mathrm{SiO}_{2}\right)$

$>$ Tricalcium aluminate $\left(3 \mathrm{CaO} \cdot \mathrm{Al}_{2} \mathrm{O}_{3}\right)$

$>$ Tetracalcium aluminoferrite $\left(4 \mathrm{CaO} \cdot \mathrm{Al}_{2} \mathrm{O}_{3} \cdot \mathrm{Fe}_{2} \mathrm{O}\right)$

The ordinary Portland cement was classified in to three grades, namely 33grades, 43 grades and 53 grades depending upon the strength of the cement at 28 days when tested as per IS 4031-1988. If 28 days strength is not less than $53 \mathrm{~N} / \mathrm{mm}^{2}$, it is called 53 grade cement. It is proposed to study the properties of high strength concrete of grade M25. Adopting 53 grade cement for the study.

\section{Recycled aggregate properties:}

Recycled aggregate of wide grading curve (a single grade, e.g. 0/32 mm), are used as fine and coarse aggregate. The recycled waste of bricks, concrete, asphalt, mixed building waste, various types of aggregates and soil. Recycled masonry and concrete waste, can be graded according to the customer's requirements at the most strict grading when the recycled material should be used as aggregate in ordinary concrete.

Since there are many unsolved problems encountered in controlling the quality of recycled aggregates (RA), which include low compressive strength, wide variability of quality, high drying shrinkage, large creep and low elastic modulus, applications of are hampered.

These problems are mainly resulted from the following two reasons

Construction and demolition waste materials are always contaminated with foreign materials (glass, wood, soil, plaster, tile etc.).

\begin{tabular}{|l|c|c|c|c|c|c|c|c|c|}
\hline $\begin{array}{c}\text { Sieve size } \\
\mathrm{mm}\end{array}$ & 0.20 & 0.63 & 1 & 2 & 4 & 8 & 16 & 25 & 32 \\
\hline $\begin{array}{l}\text { Passing } \\
\%\end{array}$ & 2.59 & 6.34 & 8.54 & 13.63 & 22.88 & 43.37 & 87.84 & 98.29 & 100 \\
\hline
\end{tabular}

Recycled aggregate particles are always attached with substantial amount of relatively soft cement mortar paste, making these aggregates more porous and less resistant to mechanical attacks.

Generally some modifications to the mix proportion are needed in the production of recycled aggregates, which can then be produced with the same production procedure as the conventional concrete does. However, such an approach will produce concrete with poorer quality, depending directly on the proportion of RA added. Hence, most studies recommend a limit of $30 \%$ of RA. Many researchers have successfully applied RA on pavement and roadwork or simple structures, underground structures, foundations, piles and mass concrete. However, its application to higher grade concrete is not common. These weaknesses of RA, including high porosity, high amount of cracks, high level of sulphate and chloride contents, high level of impurity and high cement mortar remains, will affect the mechanical performance of RA. The prerequisite in applying RA to high-grade concrete is to overcome these weaknesses.

The amount RA which could be recycled will depend mainly on factors such as

$>$ Location of the demolition site and of the manufacturing site.

- Level of contamination in the C\&DW as a result of unsuitable materials used in the original construction or caused by poor segregation during the demolition process.

$>$ Local demand for the material that varies depending on current development and infrastructure projects.

Demolition contractors typically use jaw crushers or impact crusher which will process material more slowly to produce a crushed concrete and masonry of a particle size of $0-8,8-32,32-64,>64 \mathrm{~mm}$. Screening after the material has been crushed is necessary to control the particle size of the finished product. The particle size of material required to manufacture new concrete will require demolition contractors to invest in new screens in order to produce the correctly graded material. 
International Journal of Trend in Scientific Research and Development (IJTSRD) ISSN: 2456-6470

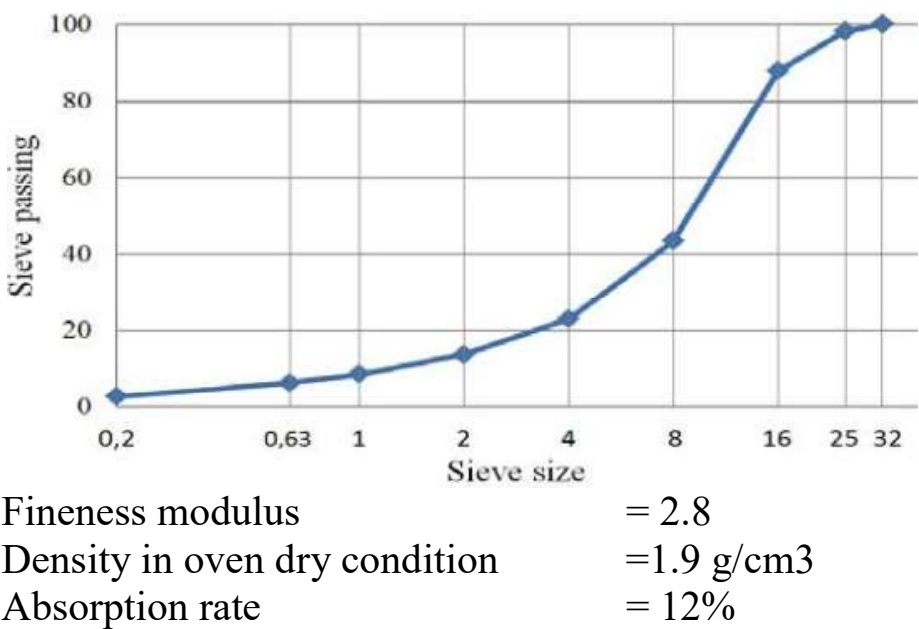

Water

Water is needed for the hydration of cement and to provide workability during mixing and for placing. Portable tap water available in the laboratory with $\mathrm{pH}$ value of 7.0 and conforming to the requirements of IS456-2000 is used for making concrete and curing the specimen as well.

\section{Fibres}

This fiber was prepared by cutting the used mineral water bottle with size such as nominal length of $40 \mathrm{~mm}$, average width of $1.4 \mathrm{~mm}$ and /average thickness of $0.6 \mathrm{~mm}$ The fiber had an aspect ratio of 90 and specific gravity of 1 . The average tensile strength of the fiber was $100 \mathrm{MPa}$.

\section{Mix design for M25}

A. Grade designation

M25

B. Maximum nominal size of aggregate $: 20 \mathrm{~mm}$ (angular)

C. Degree of quality control

D. Type of exposure

E. Degree of supervision

F. Maximum water-cement ratio

G. Minimum cement content

H. Maximum cement content

:good

:mild

:good

$: 0.45$

$: 300 \mathrm{~kg} / \mathrm{m}^{3}$

$: 450 \mathrm{~kg} / \mathrm{m}^{3}$

\section{TEST DATA FOR MATERIALS}

A. Type of cement used

B. Specific gravity of cement

:OPC53 grade

C. Specific gravity
I. Coarse aggregate
$: 2.6$
II. Fine aggregate
$: 2.5$

D. Water absorption

I. Coarse aggregate

II. Fine aggregate

E. Free (surface) moisture
2. TARGET MEAN STRENGTH OF CONCRETE

$$
\mathrm{f}^{\prime}{ }_{\mathrm{ck}}=\mathrm{f}_{\mathrm{ck}}+1.65 \times \mathrm{S}
$$

where

$\mathrm{f}^{\prime}{ }_{\mathrm{ck}}=$ target average compressive strength at 28 days,

$\mathrm{f}_{\mathrm{ck}}=$ characteristic compressive strength at 28 days,

$\mathrm{S}=$ standard deviation.

$\mathrm{S}=5$, from table-1(IS 10262:2009)

Therefore, $\quad \mathrm{f}^{\prime}{ }_{\mathrm{ck}}=25+1.65 \times 4$

$$
=31.6 \mathrm{~N} / \mathrm{mm}^{2}
$$

\section{SELECTION OF WATER CEMENT RATIO}

From table-5 of IS 456, maximum water-cement ratio $=0.5$

Adopt $\mathrm{w} / \mathrm{c}=0.45$ $0.45<0.5$, hence ok.

\section{SELECTION OF WATER CONTENT}

From table-2, of IS10262:2009

Maximum water content $=186$ litre(for 25 to $50 \mathrm{~mm}$ slump range)

For $20 \mathrm{~mm}$ aggregate

\section{DETERMINATION OF CEMENT CONTENT}
Water cement ratio

$$
\begin{aligned}
& =0.45 \\
& =186 / 0.45
\end{aligned}
$$
Cement content$$
=413.33 \mathrm{~kg} / \mathrm{m}^{3}
$$

From table-5(IS 456), the minimum cement content

$=300 \mathrm{~kg} / \mathrm{m}^{3}$

\section{CALCULATION OF AGGREGATE}

From table-3 (IS 10262)

For $20 \mathrm{~mm}$ aggregate,

Volume of coarse aggregate $=0.62$

Volume of fine aggregate $\quad=1-0.62$

$=0.38$

7. CALCULATION CEMENT AND WATER CONTENT

Volume of cement $=$ mass of cement $/($ specific gravity $\mathrm{x} 1000)$

$$
=0.133 \mathrm{~m}^{3}
$$

Volume of water = mass of water / (specific gravity $\mathrm{x} 1000)$

$=0.186 \mathrm{~m}^{3}$

\section{DETERMINATION OF COARSE AND FINE} AGGREGETE CONTENT

$1 \mathrm{~m}^{3}$ concrete $=$ volume cement + volume of water +volume of aggregete 
International Journal of Trend in Scientific Research and Development (IJTSRD) ISSN: 2456-6470

Volume of total aggregate $\quad=1-($ volume of cement

+ volume of water)

$=1-(0.133+0.186)$

$=0.683 \mathrm{~kg} / \mathrm{m}^{3}$

Volume of fine aggregate $\quad=0.26$

Volume of coarse aggregate $=0.42$
10. MIX PROPORTION

Cement

Water

Fine aggregate

Coarse aggregate

C: W : F.A : C.A
$=413.33 \mathrm{~kg} / \mathrm{m}^{3}$

$=186 \mathrm{~kg} / \mathrm{m}^{3}$

$=648.85 \mathrm{~kg} / \mathrm{m}^{3}$

$=1101 \mathrm{~kg} / \mathrm{m}^{3}$

$1: 0.45: 1.57: 2.66$

9. CALCULATION OF WEIGHT PER CUBIC

\section{TRIAL MIXES:} METER

Weight of cement

$$
=3.1 \times 1000 \times 0.133
$$$$
=413.33 \mathrm{~kg} / \mathrm{m}^{3}
$$

Weight of water

$$
=1 \times 1000 \times 0.186
$$

$$
=186 \mathrm{~kg} / \mathrm{m}^{3}
$$

\section{Cement}

Water

$$
\begin{aligned}
& =413.33 \mathrm{~kg} / \mathrm{m}^{3} \\
& =186 \mathrm{~kg} / \mathrm{m}^{3}
\end{aligned}
$$

Fine aggregate + Coarse aggregate $\quad=1750 \mathrm{~kg} / \mathrm{m}^{3}$ Aggregate are replaced by recycled aggregate by $0 \%$, $25 \%, 50 \%, 100 \%$.

Weight of fine aggregate $=0.638 \times 0.38 \times 1000 \times 2.5$ $=648.85 \mathrm{~kg} / \mathrm{m}^{3}$

Weight of coarse aggregate $=0.638 \times 0.62 \times 1000 \times 2.6$

\begin{tabular}{|c|c|c|c|c|c|c|}
\hline Mix & $\begin{array}{l}\% \text { of } \\
\text { Bottle }\end{array}$ & $\begin{array}{c}\% \\
\text { Recycled } \\
\text { Aggregate }\end{array}$ & $\begin{array}{c}\text { Fine \& Coarse } \\
\text { Aggregate } \\
\text { kg/m }\end{array}$ & $\begin{array}{l}\text { Water } \\
\mathrm{kg} / \mathrm{m}^{3}\end{array}$ & $\begin{array}{c}\text { Cement } \\
\mathrm{kg} / \mathrm{m}^{3}\end{array}$ & $\begin{array}{c}\text { Recycled } \\
\text { Aggregate } \\
\mathrm{kg} / \mathrm{m}^{3}\end{array}$ \\
\hline A & & 0 nfe & naf 1750 & Dur 186 & 415 & 0 \\
\hline $\mathrm{B}$ & & 10 & 0 & 186 & 415 & 438 \\
\hline $\mathrm{C}$ & & 20 & enor 0 Sc & ent 186 & 415 & 875 \\
\hline $\mathrm{D}$ & & 30 & 0 & 186 & 415 & 1750 \\
\hline $\mathrm{E}$ & & 0 & 1750 & 186 & 411 & 0 \\
\hline $\mathrm{F}$ & & $\circ$ & deve 0 om & net 186 & 411 & 438 \\
\hline $\mathrm{G}$ & & 50 & 0 & 186 & 411 & 875 \\
\hline $\mathrm{H}$ & & 100 & $0=0$ & 70186 & 411 & 1750 \\
\hline I & \multirow{4}{*}{$20 \%$} & 0 & 1750 & 186 & 407 & 0 \\
\hline $\mathrm{J}$ & & 25 & 0 & 186 & 407 & 438 \\
\hline $\mathrm{K}$ & & 50 & 0 & 186 & 407 & 875 \\
\hline $\mathrm{L}$ & & 100 & $\begin{array}{l}0 \\
-\quad 0\end{array}$ & 186 & 407 & 1750 \\
\hline $\mathrm{M}$ & \multirow{4}{*}{$30 \%$} & 0 & 1750 & 186 & 403 & 0 \\
\hline $\mathrm{N}$ & & 25 & 0 & 186 & 403 & 438 \\
\hline $\mathrm{O}$ & & 50 & 0 & 186 & 403 & 875 \\
\hline $\mathrm{P}$ & & 100 & 0 & 186 & 403 & 1750 \\
\hline
\end{tabular}

$$
=1101 \mathrm{~kg} / \mathrm{m}^{3}
$$

Cement is partially replaced pet bottle by $0 \%, 1 \%$, $2 \%, 3 \%$

\section{PROPORTIONS:}

so that a good mix is achieved. Concrete is then

\section{MIXING SEQUENCES}

A rotary drum mixture machine is used to get the good quality of concrete. In the mixer machine, at first the aggregates are added prior to the PET fibers. Then fiber is added and these dry ingredients are mixed for about two minutes so that the fibers are evenly distributed throughout the mix.

Special care is taken so as to ensure no fiber balls are formed. After that cement is added and these dry ingredients are mixed for about one minute. Water is added after one minute and mixed for about 5 minutes placed in the moulds in three layers and a tamping rod (ASTM C 31/C 31M) of $600 \mathrm{~mm}$ long and $16 \mathrm{~mm}$ diameter is used to compact each layer. The number of roddings is 25 and falling height is $300 \mathrm{~mm}$ from top surface of layer. After finishing the compaction, a trowel is used to make the top surface smooth.

The moulds are then kept for 24 hrs. under a temperature of $250^{\circ} \mathrm{C}$ to $320^{\circ} \mathrm{C}$ to set the concrete. 
After $24 \mathrm{hrs}$ the specimens are de-moulded and kept in the water tank for 28 days curing period.

\section{Compressive Strength of Concrete}

This tests were carried out in accordance with IS 5161999 standards conducted on concrete specimen size $150 \mathrm{~mm} \times 150 \mathrm{~mm} \times 150 \mathrm{~mm}$. The specimens which are submerged in clean fresh water is taken out after 7 days and 28 days for testing and kept in dry place so that the water is drained well to get better results. The specimen is loaded in the compression testing machine as shown in Figure. The load is gradually applied until it fails.

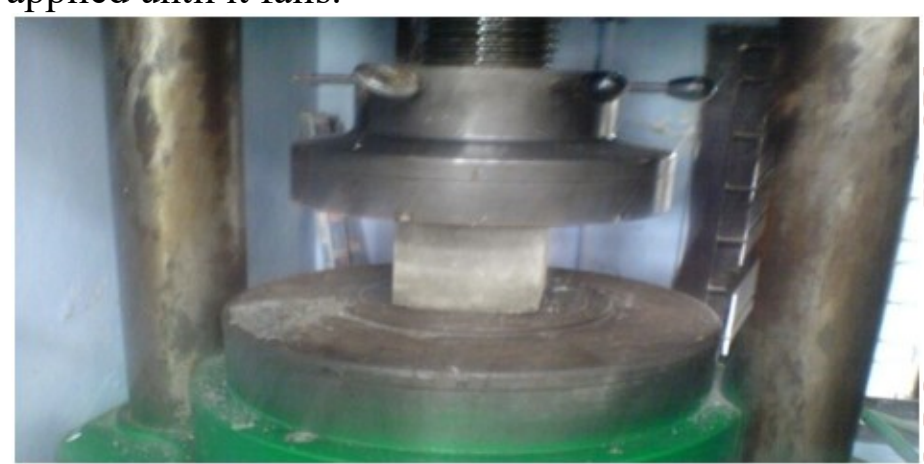

The compressive strength calculated by using formula

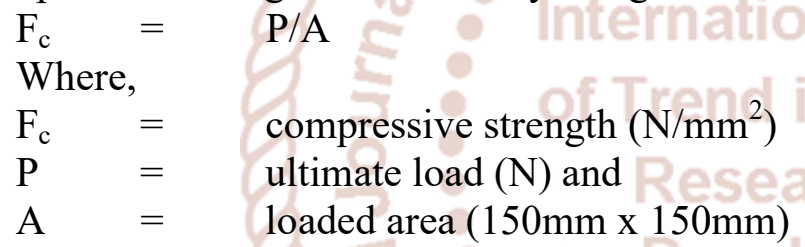

\section{Split tensile strength:}

This tests were carried out in accordance with IS 5161999 standards conducted on concrete cylinders of $150 \mathrm{~mm}$ diameter and $300 \mathrm{~mm}$ length. The cylindrical specimen are placed horizontally between the loading surfaces of a compression testing machine and the load is applied until failure of the cylinder along the vertical diameter. The failure load is noted. The splitting tensile strength is calculated using the formula.

Where,

$$
\mathrm{F}_{\mathrm{t}}=2 \mathrm{P} / \pi \mathrm{ld}
$$

$\mathrm{P}$ is the compressive load at which the cylinder will fail

1 is the length of cylinder $-300 \mathrm{~mm}$

$\mathrm{d}$ is the diameter- $150 \mathrm{~mm}$

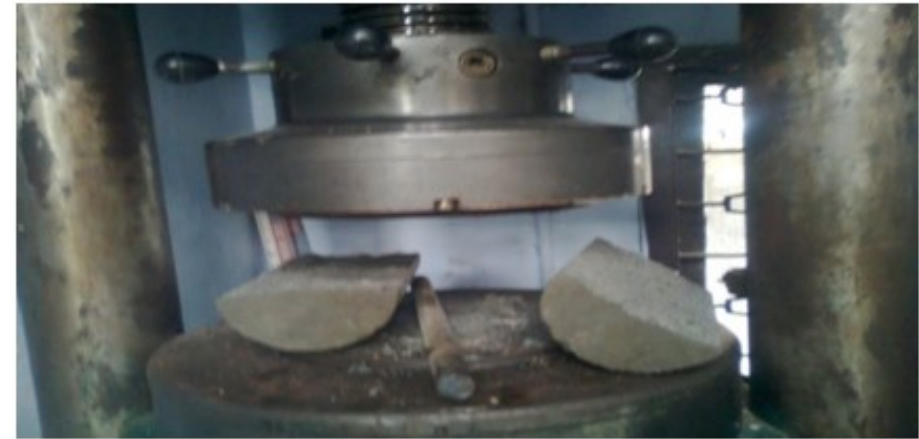

\section{Flexural Strength of Concrete}

Determination of flexural strength is essential to estimate the loads at which concrete members may crack. The bearing surface of the supporting and loading rollers were wiped clean, and any loose sand or other material were removed from the surface of the specimen where they are to make contact with the rollers. The specimen was then placed in the machine in such a manner that the load was applied to the uppermost surface as cast in the mould, along two lines spaced $13.3 \mathrm{~cm}$ apart. The axis of the specimen was carefully aligned with the axis of the loading devise. No packing was used between the bearing surface of the specimen and the rollers. The load was applied without shock and increasing continuously. Then ' $a$ ' is the distance between the line of fracture and the nearer support. The line of fracture measured on the centre line of the tensile side of the specimen.

Size of beam $=500 \times 100 \times 100 \mathrm{~mm}$

$$
\mathrm{f}_{\mathrm{cr}}=(\mathrm{Px} \ell) /\left(\mathrm{bxd} \mathrm{d}^{2}\right)
$$

\section{Where,}

$b=$ ensured width in the specimen

$\mathrm{d}=$ measured depth in $\mathrm{cm}$ of the specimen at the point of failure

$\ell=$ length in $\mathrm{cm}$ of the span on which the specimen was supported

The failure pattern of Flexural Strength of Concrete is shown in Figure

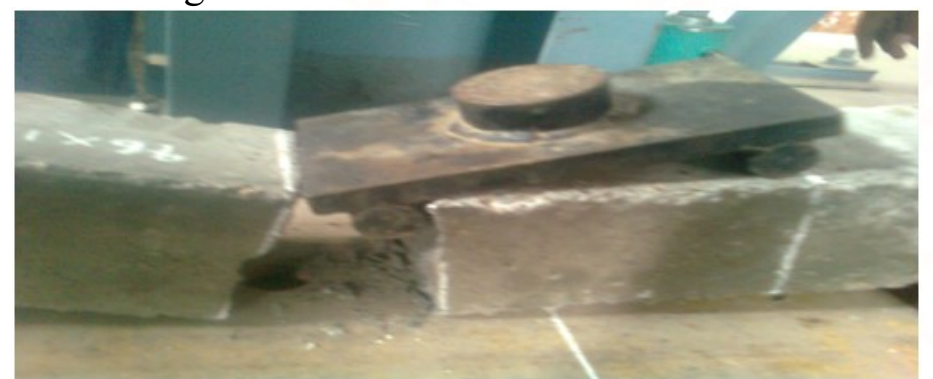


International Journal of Trend in Scientific Research and Development (IJTSRD) ISSN: 2456-6470

\section{Specimen Casting:}
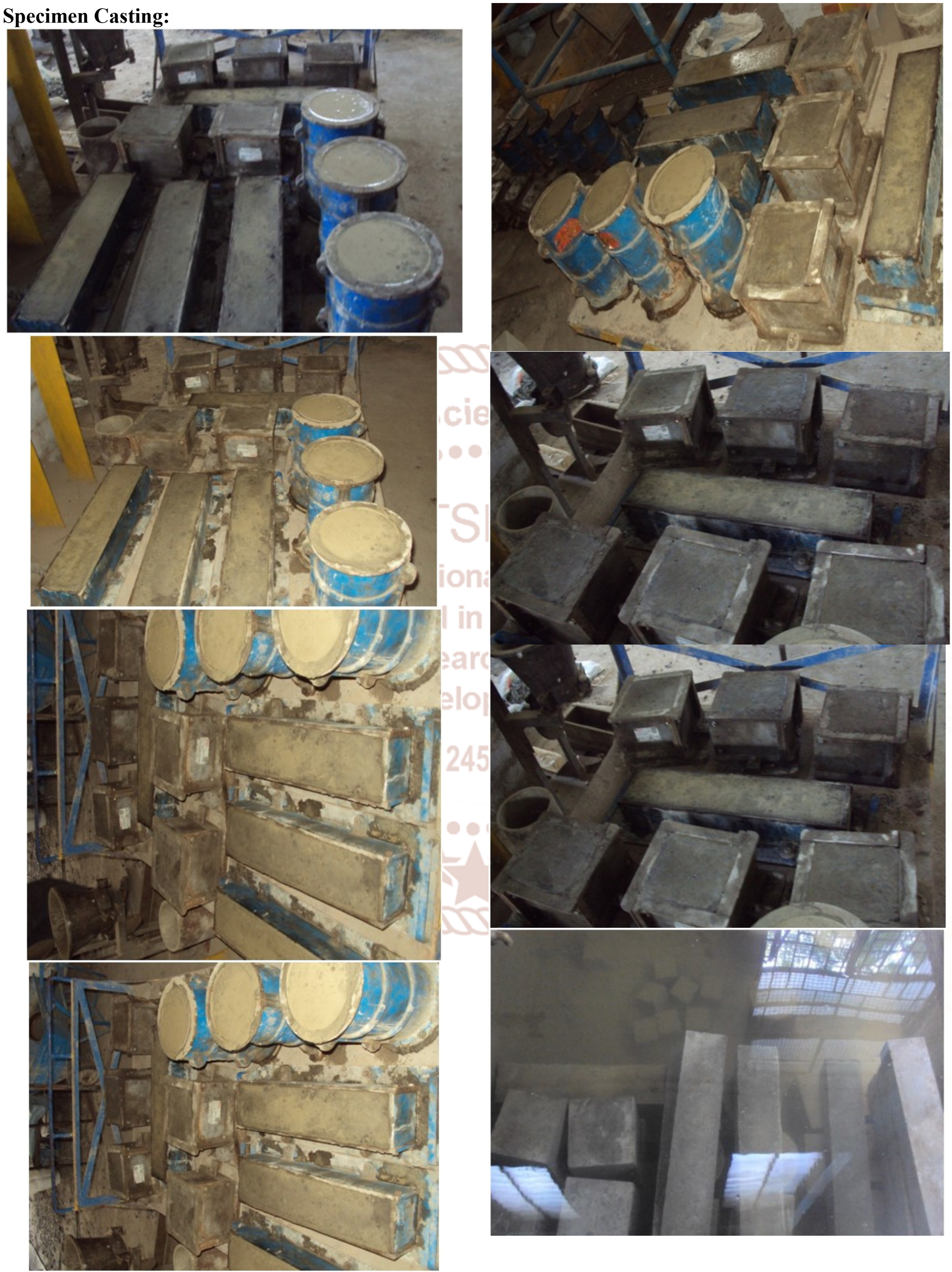
International Journal of Trend in Scientific Research and Development (IJTSRD) ISSN: 2456-6470
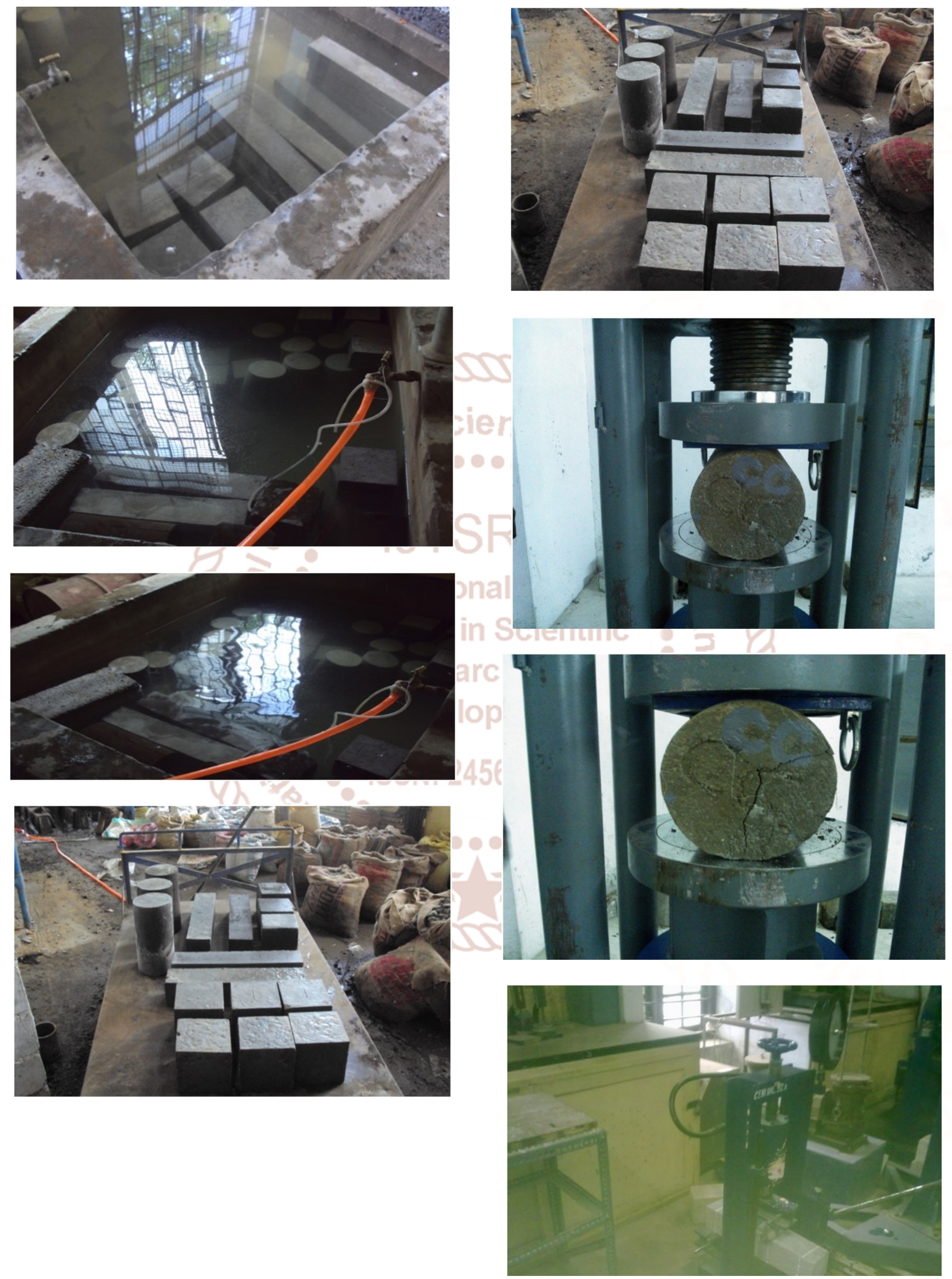
International Journal of Trend in Scientific Research and Development (IJTSRD) ISSN: 2456-6470

TEST RESULTS:

\begin{tabular}{|c|c|c|c|c|c|}
\hline Mix & $\begin{array}{l}\% \text { of } \\
\text { Bottle } \\
\end{array}$ & $\begin{array}{l}\text { \% Recycled } \\
\text { Aggregate } \\
\end{array}$ & $\begin{array}{l}\text { Compressive } \\
\text { Strength }\left(\mathrm{N} / \mathrm{mm}^{2}\right) \\
\end{array}$ & $\begin{array}{l}\text { Split tensile } \\
\text { Strength }\left(\mathrm{N} / \mathrm{mm}^{2}\right) \\
\end{array}$ & $\begin{array}{l}\text { Flexural Strength } \\
\left(\mathrm{N} / \mathrm{mm}^{2}\right)\end{array}$ \\
\hline $\mathrm{A}$ & \multirow[t]{4}{*}{$0 \%$} & 0 & 33 & 2.8 & 3.5 \\
\hline $\mathrm{B}$ & & 25 & 32 & 2.7 & 3.3 \\
\hline $\mathrm{C}$ & & 50 & 31 & 2.6 & 3.2 \\
\hline $\mathrm{D}$ & & 100 & 28 & 2.65 & 3.25 \\
\hline $\mathrm{E}$ & \multirow{4}{*}{$1 \%$} & 0 & 35 & 2.9 & 3.7 \\
\hline $\mathrm{F}$ & & 25 & 33.5 & 2.85 & 3.45 \\
\hline $\mathrm{G}$ & & 50 & 30.5 & 2.8 & 3.5 \\
\hline $\mathrm{H}$ & & 100 & 28.65 & 2.8 & 3.51 \\
\hline $\mathrm{I}$ & \multirow{4}{*}{$2 \%$} & 0 & 37 & 3.5 & 4.5 \\
\hline $\mathrm{J}$ & & 25 & 34 & 3.4 & 4.0 \\
\hline $\mathrm{K}$ & & 50 & 31.5 & 3.50 & 4.4 \\
\hline $\mathrm{L}$ & & 100 & $29->\leq>$ & 3.4 & 4.2 \\
\hline $\mathrm{M}$ & \multirow[t]{4}{*}{$3 \%$} & 0 & 35 & 3.6 & 4.0 \\
\hline $\mathrm{N}$ & & $C$ & 30 scle & 3.3 & 3.96 \\
\hline $\mathrm{O}$ & & $50 \longrightarrow$ & 28 & $3.1 C^{\circ} \quad \Delta$ & 3.95 \\
\hline $\mathrm{P}$ & & 100 & 26 & 3.4 & 3.94 \\
\hline
\end{tabular}
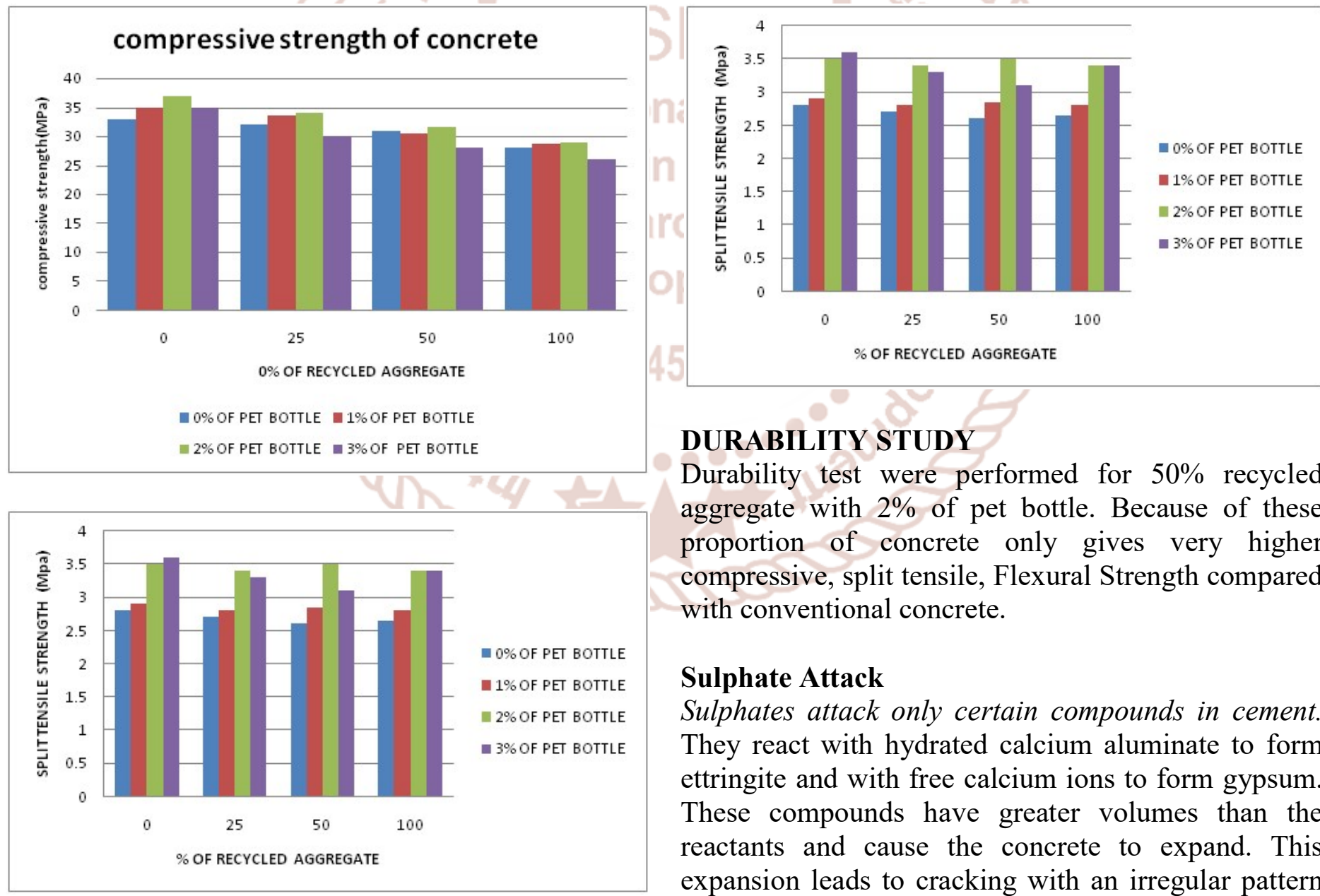

\section{DURABILITY STUDY}

Durability test were performed for $50 \%$ recycled aggregate with $2 \%$ of pet bottle. Because of these proportion of concrete only gives very higher compressive, split tensile, Flexural Strength compared with conventional concrete.

\section{Sulphate Attack}

Sulphates attack only certain compounds in cement. They react with hydrated calcium aluminate to form ettringite and with free calcium ions to form gypsum. These compounds have greater volumes than the reactants and cause the concrete to expand. This expansion leads to cracking with an irregular pattern This gives easier access to sulphates for further penetration. The process continues till the complete disintegration and destruction of concrete. The cracking and disintegration depends on 
International Journal of Trend in Scientific Research and Development (IJTSRD) ISSN: 2456-6470

$>$ Exposure condition, i.e., the amount of aggressive substance

$>$ Permeability of concrete

$>$ Susceptibility of concrete (type of cement)

$>$ Amount of water available.

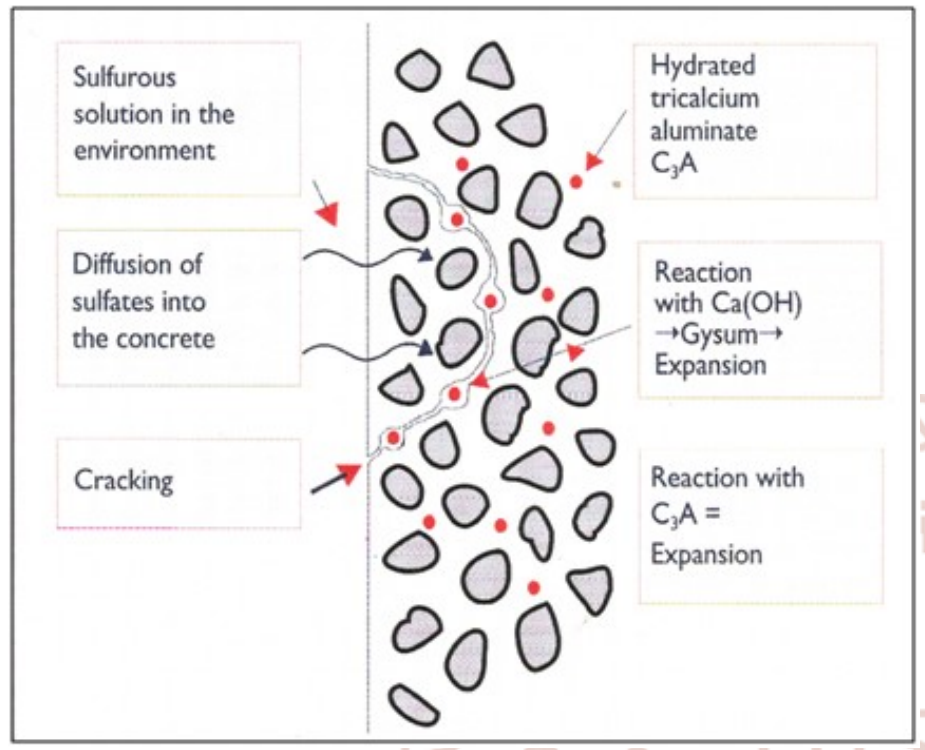

\section{Schematic Diagram of Sodium Sulphate Attack}

An experimental study was undertaken to evaluate the relative chemical resistance of recycled concrete contains $2 \%$ of pet bottles and $50 \%$ of recycled aggregate to the following solution; $1 \% \mathrm{H}_{2} \mathrm{SO}_{4}, 1 \%$ $\mathrm{HCl}$ and 5\% ammonium sulphate. Sulphuric acid and hydrochloric acid were used for acid resistance study and sulphate resistance was determined by ammonium sulphate. Time taken to register $25 \%$ weight loss by fully submerged concrete specimens was used as a criterion for failure. In the present study $150 \mathrm{~mm}$ cubes were used for testing and the concrete specimens were undergoes alternate wetting and drying process for a 15 days interval. The figure shows the specimen immersed in chemical solutions.
The weight loss of the specimens determined as follows:

$$
\text { Weight loss }(\%)=\frac{(\mathrm{W} 1-\mathrm{W} 2)}{\mathrm{W} 1} \times 100
$$

Where ' $\mathrm{W} 1$ ' is the weight of the specimens before immersion and 'W2' is the weight of cleaned specimens after immersion.

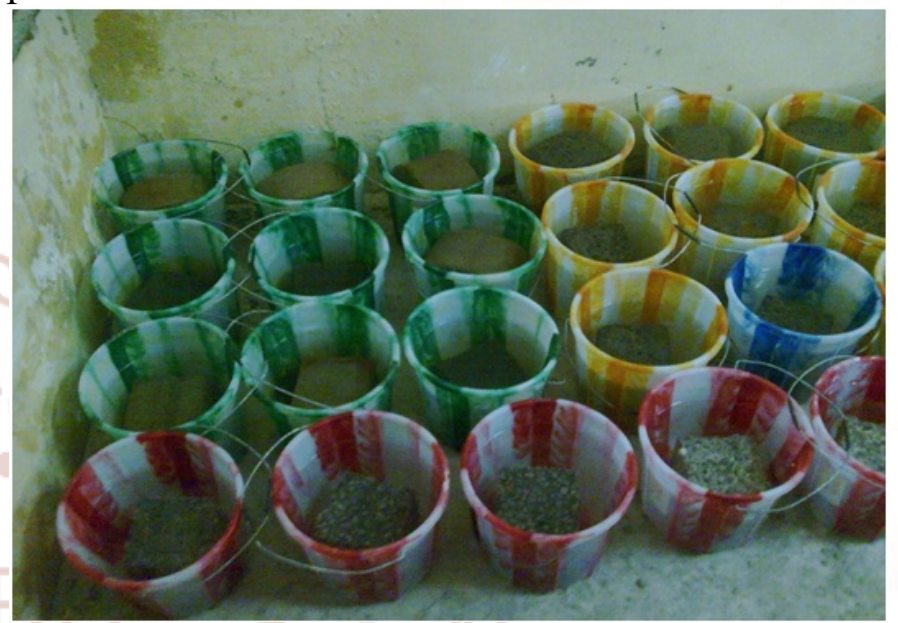

Chemical Resistance Test

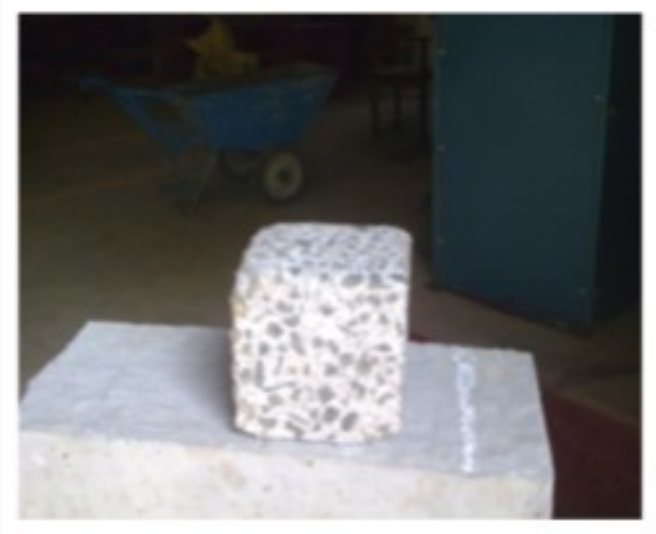

\section{SULPHATE RESISTANCE TEST}

\begin{tabular}{|c|c|c|c|c|}
\hline \multirow{2}{*}{$\begin{array}{c}\text { S. } \\
\text { No }\end{array}$} & \multirow{2}{*}{ Mix ID } & $\begin{array}{c}\text { Initial weight } \\
\text { (Weight after }\end{array}$ & $\begin{array}{c}\text { Final weight (After } \\
\mathbf{3 0} \text { days immersion } \\
\text { in } \mathbf{M g S 0}_{4} \text { ) }\end{array}$ & \% of Weight loss \\
\hline \multirow{3}{*}{1} & \multirow{3}{*}{ Conventional concrete } & 8.678 & 8.665 & 0.10 \\
\cline { 3 - 5 } & & 8.646 & 8.642 & 0.04 \\
\cline { 3 - 5 } & & 8.652 & 8.647 & 0.05 \\
\hline \multirow{2}{*}{2} & \multirow{2}{*}{$\begin{array}{c}\text { Concrete made 25\%of recycled } \\
\text { aggregate with 2\% of pet bottle }\end{array}$} & 8.435 & 8.428 & 0.08 \\
\cline { 3 - 5 } & & 8.457 & 8.454 & 0.03 \\
\cline { 3 - 5 } & & 8.402 & 8.398 & 0.04 \\
\hline
\end{tabular}




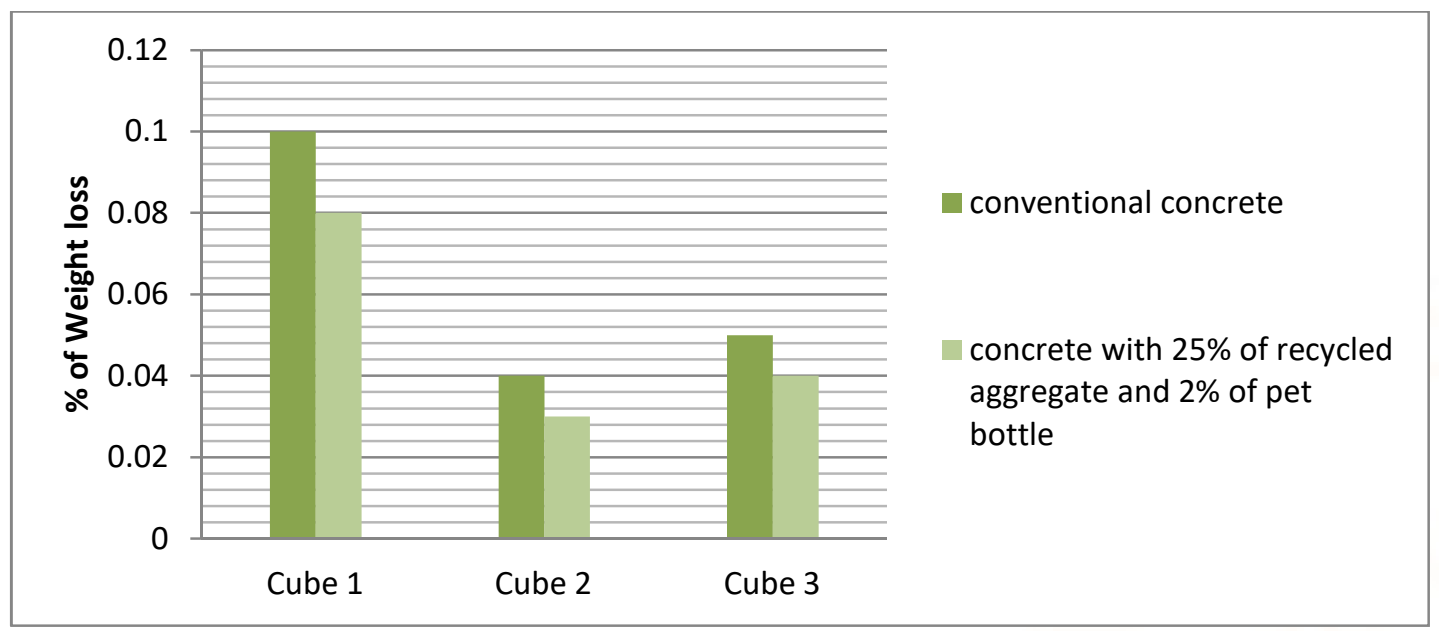

\section{CONCLUSION}

Use of plastics is growing worldwide day by day and as such huge quantities of plastic waste are generated every day which are non-biodegradable and cause lot for environmental pollution and are very hazardous to human being and animals. Based on experimental research for Concrete made with pet bottle and recycled aggregate partially replaced and the following conclusions can be drawn at 28 days. The pet bottle added in concrete about $0 \%, 1 \%, 2 \%, 3 \%$

Replaced by cement content and $25 \%, 50 \%, 75 \%$ of recycled aggregate replaced by aggregate.

The test results shows that the use of $2 \%$ of pet bottle with $25 \%$ of recycled aggregate increase the compressive strength about $1.51 \%$, the split tensile strength is increased by $3.54 \%$,but the flexural strength is $1.75 \%$.

\section{REFERENCES}

1. M.S. Shetty, "Concrete Technology", S. Chand \& Company Ltd, Ram Nagar New Delhi, 2005.

2. V. Vytlačilová, "Fibre Concrete with Recycled Aggregates as a Full Substitution of Natural Aggregates", Dissertation, Prague, 2009.

3. Marek, C. R., Gallaway, B. M., and Long, R. E., "Look at Processed Rubble - It is a Valuable Source for Aggregates: Roads and Streets", Vol. 114, No. 9, Sept. 1971, p. 82-85.

4. Barra, M and Vazquez, E, "Properties of Concrete with Recycled Aggregates: Influence of the Properties of the Aggregates and Their Interpretation", Proceedings of the International Symposium organized by the Concrete Technology Unit, London, 1998.
5. Ghosh, S. N., "Progress in Cement and Concrete", Science \& Technology, Thomas Telford, Pt. I, Vol. I, 1992.

6. Rao, Akash, K.N Jha, and Sudhir Misra, "A framework for use of construction and demolition waste as recycled aggregate in India", The Indian Concrete Journal, January, 2006.

7. "Environmental Protection Department. Environment Hong Kong: A Review of 1999”, Environmental Protection Department, Hong Kong Government Printer, 2000.

8. Environmental Protection Department, "Waste Reduction Framework Plan 1998", 2007. The Government Printer, Hong Kong.

9. C. S. Poon, T. W. A. T. W. Yu, and L.H. Ng, "Onsite sorting of construction and demolition waste in Hong Kong", Resources Conservation \& recycling, 32, 2001, p.157-172.

10. T. C. Hansen, Recycling of Demolished Concrete and Masonry, RIELM Report No. 6, E \& FN Spon, UK 1992.

11. R.J. Collins, "The use of recycled aggregates in concrete", BRE report, Building Research Establishment, U.K., May 1994.

12. P.K. Mehta and P. J. M. Monteiro, "Concrete: Structures, Properties, and Materials", New Jersey, Prentice Hall, 1993.

13. P.T. Sherwood, "Alternative Materials in Road Construction”, London, Thomas Telford, 1995.

14. J. Desmyster and J. Vyncke, "Proceedings of the st

1 ETNRECY, NET/RILEM Workshop, on use of Recycled Materials as Aggregates in Construction Industry" (posters), ETNRECY, NET, Paris, 2000. 
International Journal of Trend in Scientific Research and Development (IJTSRD) ISSN: 2456-6470

15. C. F. Hendriks and H.S. Pieterson, "Concrete: durable but also sustainable", Proceedings of International Conference on the Use of Recycled Concrete Aggregates, Edited by D.K. Dhir, N.A. Henderson and M.C. Limbachiya, Thomas Telford, U.K., 1998, p1-18.

16. M. Kikuchi, Y. Dosho, M. Narikawa, and T. Miura, T. "Application of Recycled Aggregate Concrete for Structural Concrete, Part-I: Experimental Study on the Quality of Recycled Aggregate and Recycled Aggregate Concrete", Proceedings of the International Conference on the Use of Recycled Concrete Aggregates. Edited by: D. K. Dhir, N. A. Henderson and M. C. Limbachiya, Thomas Telford, UK., 1998, p55-68.

17. R. Putnam, "Concrete Block Construction", $3^{\text {rd }}$ edition, American Technical Society, Chicago, U.S.A., 1973.

18. R. J. Collins, D.J. Harris and W. Sparkes, "Blocks with recycled aggregate: beam-and-block floors", BRE report, Building Research Establishment, U.K., October 1998.

19. BS 6073: Part 1: 1981, "Precast concrete masonry units, Part 1. Specification for precast concrete masonry units", British Standards Institution.

20. Akcaozoglu, S., Atis, C. D. and Akcaozoglu, K (2010). An investigation on the use of shredded waste PET bottles as aggregate in lightweight concrete. Waste Management

21. Choi, Y. W., Moon, D. J., Chung, J. S. and Cho, S.K. (2005). Effects of waste PET bottles

22. Aggregate on the properties of concrete. Cement and Concrete Research, 35, 776-781.

23. Frigione, M. (2010). Recycling of PET bottles as fine aggregate in concrete. Waste Management, 30, 1101-1106.

24. Hopewell, J., Dvorak, R. and Kosoir, E. (2009). Plastic recycling: challenges and opportunities. Phil. Trans. R. Soc. B(2009)364, 2115-2126.

25. Ismail, Z. Z. and Al-Hashmi, E. A. (2008). Use of waste plastic in concrete mixture as aggregate replacement. Waste Management, 28, 2041-2047.

26. IS: 383-1970 Specifications for coarse and fine aggregates from natural sources for concrete (Second revision).

27. IS:10262-2009 Recommended gudelines for concrete mix design.
28. Lopes Lima, P.R., Leite, M.B. and Ribeiro Santiago, E. Q. (2010). Recycled lightweight

29. concrete made from footwear industry waste and CDW. Waste Management , 30, 1107-1113

30. American Concrete Institute (ACI) Committee 555, "Removal and Reuse of Hardened Concrete,"ACI 555R-01, American Concrete Institute, Farmington Hills, MI, 2001.

31. American Concrete Paving Association (ACPA), "Recycling Concrete Pavement,"TB014P, American Concrete Pavement Association, Skokie, IL, 1993, 19 Pages.

32. ASTM Committee C9, "Standard Specification for Concrete Aggregate, "ASTM C 33, ASTM International, West Conshohocken, PA, 2003.

33. Ahmad, S.H., "Properties of Concrete Made with North Carolina Recycled Coarse and Fine Aggregate, "Center for Transportation Engineering Studies, North Carolina State University, Raleigh, NC, 1996.

34. AASHTO Subcommittee on Materials, "Fine Aggregate for Portland Cement Concrete," AASHTO M 6, American Association of State Highway and Transportation Officials, Washington, DC, 2001.

35. AASHTO Subcommittee on Materials, "Coarse Aggregate for Portland Cement Concrete," AASHTO M 80, American Association of State Highway and Transportation Officials, Washington, DC, 2001.

36. Environmental Council of Concrete Organizations (ECCO), "Recycling Concrete and Masonry,"EV22, Skokie, IL, 1999, 12 Pages.

37. FHWA Policy Memorandum "Formal Policy on the Use of Recycled Materials," February 7, 2002.

38. FHWA Survey, Recycled Concrete Aggregate National Review, May 24, 2005.

39. Klieger, P. and Lamond, J.F., "Significance of Tests and Properties of Concrete-Making Materials," STP 169C, ASTM International, West Conshohocken, PA, 1994.

40. Kosmatka, S., Kerkoff, B. and Panarese, W., "Design and Control of Concrete Mixtures, 14th Edition," Portland Cement Association, Skokie, IL 2002.

41. Melton, J.S., "Guidance for Recycling Concrete Aggregate Used in the Highway Environment," 
ACI SP-219, American Concrete Institute, 44. Van Dam, T.J., Sutter, L.L., Smith, K.D., Wade, Farmington Hills, MI, 2001.

M.J., and Peterson, K.R., "Guidelines for Detection, Analysis and Treatment of MaterialsRelated Distress in Concrete Pavements Vol. 2: Guidelines Description and Use," FHWA-RD-01(NCHRP), "2002 Design Guide, Design of New and Rehabilitated Pavement Structures," NCHRP 1-37-A, Transportation Research Board, Washington, DC, 2003.

43. Stark, David, "The Use of Recycled-Concrete from Concrete Exhibiting Alkali-Aggregate Reactivity," Research and Development Bulletin RD114, Portland Cement Association, 1996.

164, Federal Highway Administration, McLean, VA, August 2002.

45. Yrjanson, William A., NCHRP Synthesis 154; "Recycling of Portland Cement Concrete Pavement," Transportation Research Board, Washington, D.C., December 1989.

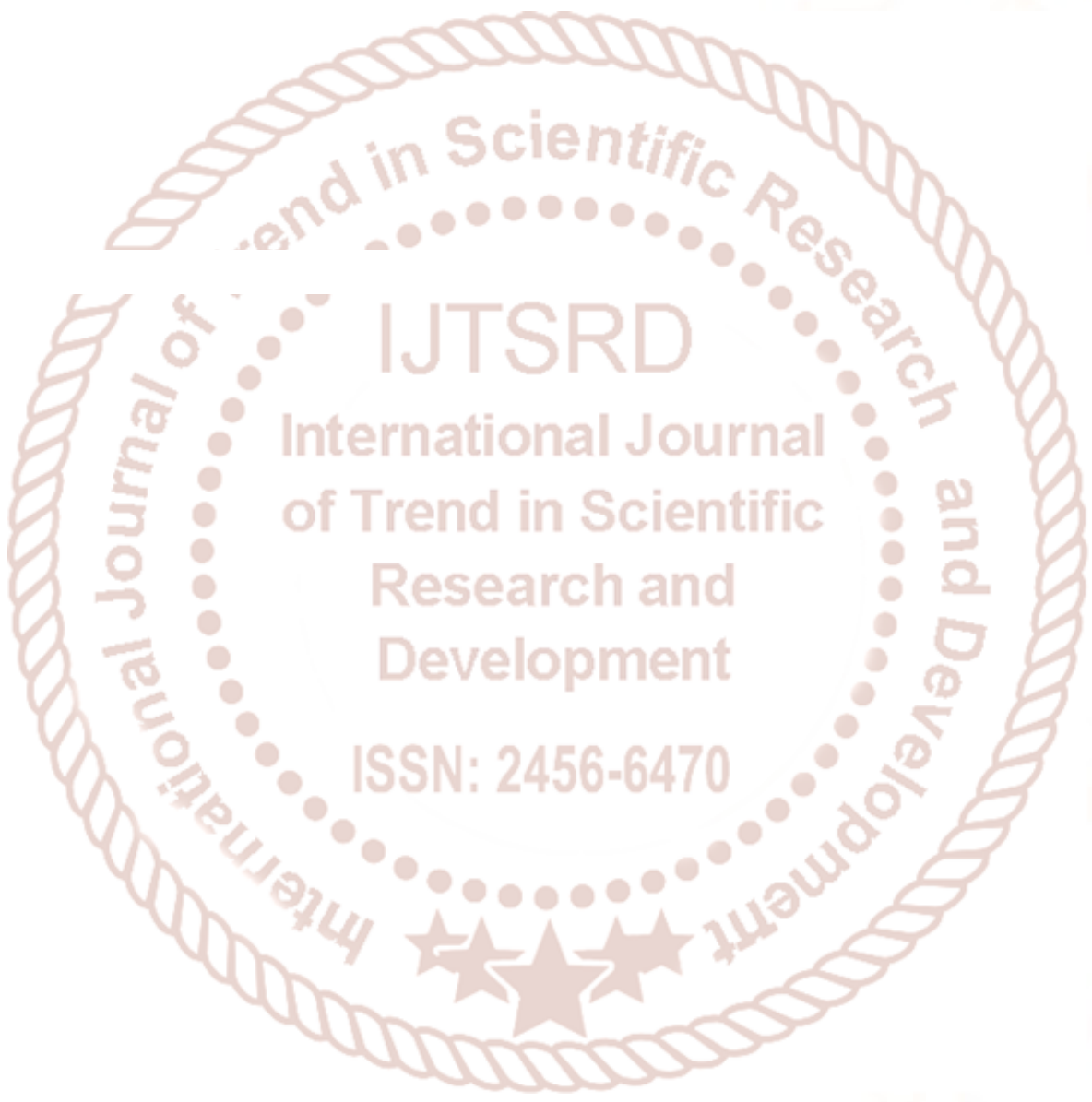

